\title{
PROGNOSIS OF BACTERIAL MENINGITIS IN CHILDREN
}

\author{
IRENIO GOMES*, AILTON MELO**, RITA LUCENA***, MARCO HELENO CUNHA-NASCIMENTO****, \\ ADRIANA FERREIRA ****, JULIETA GÓES ${ }^{* * * *}$ ISMARA BARRETO****, NEILA JONES****, \\ VERONICA GASPARI"***, EMILIA KATIANE EMBIRUÇU"***, MARIELZA VEIGA*
}

ABSTRACT - We studied the incidence and prognosis of acute neurologic complications in 281 children under 13 years of age with a diagnosis of acute bacterial meningitis. All the patients were examined daily by the same group of neurologists, using a standardized neurological examination. Patients with signs of encephalic lesions, unsatisfactory response to antibiotics or decreased level of consciousness were submitted to brain computer tomography. The overall lethality rate was $20.3 \%$ and cases whose causative agent was identified presented a higher lethality rate $(\mathbf{2 3 . 7 \% )}$ than those in which the agent was not found. The most important neurological abnormalities were meningeal signs ( $88.3 \%)$ followed by decreased consciousness $(47.7 \%)$, irritability (35.2\%), seizures (22.4\%), fontanel bulging (20.6\%) and cranial nerve palsy (14.2\%). Seizures, cranial nerve palsy and the absence of meningeal signs were related to higher rates of lethality. Diminished consciousness, seizures, subdural effusion, abscess and hydrocephalus were the most important complications, respectively. We can conclude that acute bacterial meningitis continues to be an important health problem in developing countries and that public health measures will be necessary to minimize the impact of sequelae and reduce the mortality rate in children with that pathology.

KEY WORDS: pyogenic meningitis, bacterial meningitis, septicemia, meningitis in children.

\section{Prognóstico de meningite bacteriana em crianças}

RESUMO - Para estudar os fatores prognósticos e incidência de complicações em meningite bacteriana, 281 crianças (idade abaixo de 13 anos) com quadro clínico e do LCR compatíveis com esse diagnóstico foram acompanhadas, durante o internamento, através de ficha de avaliaçāo padrão. Aquelas que apresentaram sinais de lesão encefálica, resposta inadequada ao tratamento ou diminuição do nível de consciência, com Glasgow $\leq$ 7 , foram submetidas a tomografia computadorizada de crânio. A taxa de letalidade global foi $20,3 \%$, sendo maior quando o agente etiológico foi identificado $(23,7 \%)$. As alteraçōes neurológicas mais encontradas foram: irritação meníngea, diminuição do nível de consciência, convuisōes, irritabilidade, abaulamento de fontanela $e$ comprometimento de nervos cranianos. Convulsð̌es, comprometimento de.nervos cranianos e ausência de irritação meníngea foram associados a maior letalidade. Complicaçōes neurológicas ocorreram em $58 \%$, sendo as mais frequentes diminuição do nível de consciência $(47,7 \%)$, convulsôes $(22,4 \%)$, coleção subdural $(3,2 \%)$, abscesso(2,5\%) e hidrocefalia $(2,5 \%)$. Observamos que meningite bacteriana continua sendo problema de saúde publica em países em desenvolvimento e que medidas para redução da morbidade e mortalidade desta doença são necessárias.

PALAVRAS-CHAVE: meningite piogênica, meningite bacteriana, septicemia, meningite em crianças.

Although the use of antibiotics has dramatically changed the mortality of patients with pyogenic meningitis, management of neurological complications remains as a significant problem ${ }^{6 . ?}$. Fatalities may occur in spite of appropriate treatment and may be related to cerebral edema, vasculitis,

Hospital Universitário Professor Edgard Santos, Universidade Federal da Bahia (UFBA), Salvador; *Docente do Serviço de Neurologia; **Chefe do Serviço de Neurologia; ***Pós-graduanda de Neuropsicofarmacologia; ****Estagiário do Serviço de Neurologia. This paper was partially presented at the Fifth Meeting of the European Neurological Society. Aceite: 11-abril-1996.

Dr. Ailton Melo - Faculdade de Medicina UFBA - Av. Reitor Miguel Calmon, s/n - 40110-100 Salvador BA Brasil. FAX 55713580592. 
thrombophlebitis ${ }^{4,10}$ or alterations of cerebral vascular flow, as has been described in laboratory animals ${ }^{9,11}$. Most of the clinical reports on complications and mortality in bacterial meningitis have been done in developed countries ${ }^{\text {f-x,11-14}}$. In South America and Africa, despite a continued high incidence of meningitis ${ }^{1-3}$, there are few reports analyzing aspects of neurological morbidity in children with a diagnosis of pyogenic meningitis.

For this paper, we performed a prospective study in 281 children under 13 years of age, in an infectious disease hospital in Salvador (Northeastern Brazil), in order to determinate acute neurologic complications in children with pyogenic meningitis.

\section{METHODS}

The Hospital Couto Maia, a large reference hospital for the treatment of infectious diseases, located in Salvador - Bahia, Northeastem Brazil, provides healthcare services to virtually all suspected cases of community meningitis in Salvador, excluding neonatal patients.

From April to December 1993, we studied 281 patients under 13 years of age who fulfilled one of the following diagnostic criteria for pyogenic meningitis: 1, positive cerebral spinal fluid (CSF) culture for pyogenic bacteria; 2, presence of Gram-negative diplococci in CSF; 3, positive blood cultures for Neisserice meningitidis with CSF cell count over 4 cells $/ \mathrm{mm}^{3} ; 4, \mathrm{CSF}$ cell count of 1000 or more cells $/ \mathrm{mm} 3$ with more than $50 \%$ being neutrophils; 5. visualization of Gram stained bacteria in CSF. It was established that the first three criteria would identify the causative agent. Infants with a congenital or acquired abnormality of the central nervous system(CNS), a prosthetic device inserted into the CNS or previous episodes of bacterial meningitis were excluded.

On admission every patient underwent anamnesis and a standardized neurologic examination. Subsequently, patients were given follow up exams in hospital wards. A CT scanning was performed in patients who presented: signs of encephalic lesions, a diminished level of consciousness, less than 7 on the Glasgow coma scale, an unsatisfactory response to the proper therapeutic treatment.

All information was recorded in questionaries filled out by the examiners and entered in a computer file created in Fox Pro version 2.5. The data were analyzed with the help of a statistical software program, EPIINFO version $5.0 \mathrm{lb}$.

Five children were removed to other health care unities and the lethality was calculated with a total of 276 patients.

\section{RESULTS}

There were $158(56.2 \%)$ males and $123(43.8 \%)$ females. Etiologic agents were identified in 208 (74\%) cases with a predominance of $H$. influenzae, followed, respectively, by $N$. meningitidis and S.pneumoniae (Table1). H. influenzae was the primary causative agent in children four years of age or younger. After that age group, $N$. meningitides was the primary etiologic agent. S. pneumoniae was the second in importance only after the age of nine. Other agents like Citrobactersp., S. aureus. and Klebsiella sp. occurred less frequently (3.2\%). The etiologic distribution in children aged 2 months or younger was very unusual due to the low number of cases in this age group.

Table I. Etiologic distribution according to age groups in 281 cases of pyogenic meningitis in children under 13 years of age admitted to HCM Hospital Couto Maia between April and December, 1993.

\begin{tabular}{lcccccc}
\hline Etiology & $\begin{array}{l}<2 \mathrm{mo} \\
\mathrm{N} .(\%)\end{array}$ & $\begin{array}{c}2-12 \mathrm{mo} \\
\mathrm{N} .(\%)\end{array}$ & $\begin{array}{c}1-4 \mathrm{yr} \\
\text { N. (\%) }\end{array}$ & $\begin{array}{c}5-8 \mathrm{yr} \\
\text { N. (\%) }\end{array}$ & $\begin{array}{c}9-12 \mathrm{yr} \\
\text { N. (\%) }\end{array}$ & $\begin{array}{c}\text { Total } \\
\text { N. (\%) }\end{array}$ \\
\hline H. influenzae & $1(11.1)$ & $41(41.8)$ & $38(48.7)$ & $6(13.0)$ & $3(6.0)$ & $89(31.7)$ \\
S. pneumonize & $3(33.3)$ & $18(18.4)$ & $4(5.1)$ & $2(43)$ & $6(12.0)$ & $33(11.7)$ \\
N. meningitidis & $3(33.3)$ & $18(18.4)$ & $17(21.7)$ & $19(41.3)$ & $20(40.0)$ & $77(27.4)$ \\
Others agents & $1(11.1)$ & $4(4.1)$ & $2(2.6)$ & $2(4.3)$ & - & $9(3.2)$ \\
Not identified & $1(11.1)$ & $17(17.3)$ & $17(21.7)$ & $17(37.0)$ & $21(42.0)$ & $73(26.0)$ \\
Total $(100 \%)$ & 9 & 98 & 78 & 46 & 50 & 281 \\
\hline
\end{tabular}


The overall lethality rate was $20.3 \%$. The rate was higher among cases with identified agents $(23.7 \%)$ than among cases with unidentified agents $(10.1 \%)$.

The most frequent clinical alterations were fever $(97.1 \%)$, vomiting $(77.2 \%)$ and somnolence $(50.2 \%)$. Respiratory infections $(24.2 \%)$, otitis $(7.5 \%)$ and otalgia $(6.4 \%)$ were the most important predisposing factors. Previous use of antibiotics was present in $17.4 \%$ of patients. Somnolence, fever and otalgia were predominating in our cases. None of these clinical alterations had any relationship with increased lethality.

The most important neurologic findings were meningeal signs $(88.3 \%)$, diminished consciousness $(47.7 \%)$, irritability (35.2\%), seizures $(22.4 \%)$, fontanel bulging $(20.6 \%)$ and cranial nerve palsy $(14.2 \%)$.

Seizures, cranial nerve palsy and an absence of meningeal signs were related to a higher mortality rate (Table 2 ).

The overall complication rate was $58 \%$ (Table 3 ) with the most common being: lowered consciousness $(47.7 \%)$; seizures $(22.4 \%)$; subdural effusion $(3.2 \%)$; brain abscess $(2.5 \%)$; hydrocephalus $(2.5 \%)$. Leukoencephalopathy $(1.4 \%)$, stroke $(1.1 \%)$, cortical atrophy $(0.4 \%)$ and encephalitis $(0.4 \%)$ were less frequent. In general the complications predominated in children under

Table 2. Lethality related to neurological signs in $276^{*}$ cases of pyogenic meningitis in children under 13 years of age admitted to HCM between April and December, 1993.

\begin{tabular}{lcccc}
\hline Neurological alterations & $\begin{array}{c}\text { Presence } \\
\text { N (letality - \%) }\end{array}$ & $\begin{array}{c}\text { Absence } \\
\text { N (letality - \%) }\end{array}$ & $\mathrm{x}^{2}$ & OR \\
\hline Seizures & $62(38.7)$ & $214(14.9)$ & 15.34 & $3.59^{* *}$ \\
Irritability & $98(21.4)$ & $178(19.6)$ & 0.04 & - \\
Diminished consciousness & $131(25.1)$ & $145(15.8)$ & 3.15 & - \\
Focal motor deficit & $9(22.0)$ & $286(20.2)$ & 0.08 & - \\
Cranial nerve palsy & $38(44.7)$ & $238(16.3)$ & 14.58 & $4.13^{* *}$ \\
Meningeal signs & $244(17.2)$ & $32(43.7)$ & 10.73 & $0.27^{* *}$ \\
Fontanel bulging *** & $50(32.0)$ & $48(31.2)$ & 0.04 & - \\
\hline
\end{tabular}

*Five children were removed to other health unities. **P $<0.001 * * *$ Children less than 1 year old (106 cuses).

Table 3. Distribution of acute neurolygic complications in pyogenic meningitis according to age groups in 281 children under 13 years of age admitted to HCM between April and December, 1993.

\begin{tabular}{lccccc}
\hline Complications & $0-1 \mathrm{yr}$ & $1-4 \mathrm{yr}$ & $5-8 \mathrm{yr}$ & $9-12 \mathrm{yr}$ & Total \\
& $\mathrm{N}(\%)$ & $\mathrm{N}(\%)$ & $\mathrm{N}(\%)$ & $\mathrm{N}(\%)$ & $\mathrm{N}(\%)$ \\
\hline Subdural effusion & $4(3.7)$ & $3(3.8)$ & $1(2.2)$ & $1(2.0)$ & $9(3.2)$ \\
Abscess & $2(1.8)$ & - & $3(6.5)$ & $2(4.0)$ & $7(2.5)$ \\
Hydrocephalus & $5(4.5)$ & $2(2.6)$ & - & - & $7(2.5)$ \\
Stroke & $1(0.9)$ & $2(2.6)$ & - & - & $3(1.1)$ \\
Leukoencephalopathy & $3(2.7)$ & $1(1.3)$ & - & - & $4(1.4)$ \\
Cortical atrophy & $1(0.9)$ & - & - & - & $1(0.4)$ \\
Encephalitis & - & $1(1.3)$ & - & - & $1(0.4)$ \\
Seizures & $41(38.4)$ & $13(16.7)$ & $2(4.3)$ & $7(14.0)$ & $63(22.4)$ \\
Diminished consciousness & $55(51.4)$ & $33(42.3)$ & $20(43.5)$ & $26(52.0)$ & $134(47.7)$ \\
Total complications & $76(71.0)$ & $39(50.0)$ & $22(47.8)$ & $26(52.0)$ & $163(58.0)$ \\
Total patients (100\%) & 107 & 78 & 46 & 50 & 281 \\
\hline
\end{tabular}


Table 4. Distribution of acute neurological complications in pyogenic meningitis according to causative agent in 281 children under 13 years of age admitted to HCM between April and December, 1993.

\begin{tabular}{lccccc}
\hline Complications & $\begin{array}{c}\text { H. influenzae } \\
\mathrm{N}(\%)\end{array}$ & $\begin{array}{c}\text { S. pneumoniae } \\
\mathrm{N}(\%)\end{array}$ & $\begin{array}{c}\mathrm{N} \text {. meningitidis } \\
\mathrm{N}(\%)\end{array}$ & $\begin{array}{c}\text { Other } \\
\mathrm{N}(\%)\end{array}$ & $\begin{array}{c}\text { Unidentified } \\
\mathrm{N}(\%)\end{array}$ \\
\hline Subdural effusion & $3(3.4)$ & $1(3.0)$ & - & - & $5(6.8)$ \\
Abscess & - & $1(3.0)$ & - & - & $6(8.2)$ \\
Hydrocephalus & $3(3.4)$ & $3(9.1)$ & - & - & $1(1.4)$ \\
Stroke & $1(1.1)$ & $1(3.0)$ & - & $1(11.1)$ & - \\
Leukoencephalopathy & $2(2.2)$ & $1(3.0)$ & - & - & $1(1.4)$ \\
Cortical atrophy & $1(1.1)$ & - & - & - & - \\
Encephalitis & $1(1.1)$ & - & - & - & \\
Seizures & $26(29.2)$ & $10(30.3)$ & $10(13.0)$ & $4(44.4)$ & $13(17.8)$ \\
Diminished consciousness & $45(50.6)$ & $20(60.6)$ & $28(36.4)$ & $7(77.8)$ & $34(46.6)$ \\
Total complications & $57(64.0)$ & $26(78.8)$ & $31(40.3)$ & $8(88.9)$ & $41(56.2)$ \\
Total patients (100\%) & 89 & 33 & 77 & 9 & 73 \\
\hline
\end{tabular}

one year of age $(71 \%)$. Subdural effusions and hydrocephalus predominated in younger children and abscess occurred mainly after four years of age.

S. pneumoniae was the etiologic agent related to the highest complication rate $(78.8 \%)$, followed by $H$. influenzae (64\%), unindentified agents $(56.2 \%)$ and $N$. meningitidis (40.3\%). Other agents, as a group, had a high rate of complications, but the number of cases is not significant. The complications in $N$. meningitidis patients were limited to reduced consciousness and seizures. Most abscess and subdural effusions occurred in cases with unidentified agents while hydrocephalus ocurred mainly in cases whose agents were $H$. influenzae and $S$. pneumoniae (Table 4).

\section{DISCUSSION}

In this study we provide evidence that pyogenic meningitis continues to be one of the most important causes of neurological sequela and mortality in children of Bahia, as has been previously described by other authors ${ }^{\mathrm{t}}$. We also showed that more than half of the 281 patients studied developed neurological complications during the acute phase of disease and these findings were more frequents in children aged one year or less.

The main predictive factors of lethality were altered consciousness and seizures. These clinical signs were most related to subdural effusion, hydrocephalus and brain abscess. In a prospective clinical study utilizing an adult population, the most important acute neurological complication during bacterial meningitis was related to cerebral edema and cerebrovascular involvement which were diagnosed using cerebral angiography and CT scan ${ }^{9}$. Although it was not possible to perform angiographies systematically, our clinical experience lead us to believe that cerebral infarct is less important in children than in adults. As we have described in our report, only three patients had stroke. Another limitation of our study is that long term follow up were possible in only a few patients, due to the characteristics of our hospital.

Subdural effusion and hydrocephalus were more comum in patients under one year of age. Brain abscesses occurred in seven patients; five patients were over four years of age, one patient were 8 months old and the other 9 months old. We were not able to find any reasonable explanation for the frequency of subdural effusion in children with meningitis. In our opinion, insufficient drainage of CSF, via the arachnoid villi cells, a common complication in cases of bacterial meningitis ${ }^{11,14}$, is more prevalent in children, which favors the development of subdural collections. In children, mainly 
in those under one year of age, a diagnosis of CNS complications is obtained only if there is an experienced team following the patients day after day. We observed that the majority of CNS complications occurred within the first days of admission and, for all age groups, $S$. pneumoniae was related to the highest lethality and complication rates. However, this observation may be understimated because we did not have the opportunity to record hearing impairment in our group of patients, which has been shown to be one of the most important sequela in cases of meningitis, mainly in patients with $S$. pneumoniae meningitis. $N$. meningitidis was related to fewer sequela and a lower mortality rate, as shown in Table 4. In some patients subdural effusion and/or abscess occupied great extensions of the brain. However, surgical procedures were not necessary in any but two of our patients with brain abscess. One patient died five days after surgery. $S$. aureus accounted for 5 (1.8\%) of the cases of bacterial meningitis in our population, but, contrary to other publications ${ }^{12}$, only two patients $(40.0 \%)$ died. Of the patients with $S$. aureus meningitis, one had a soft tissue abscess and another had endocarditis due to rheumatic fever.

The most important predictive factors for death were seizures, cranial nerve palsies and absence of meningeal signs. We believe that seizures could be related to cortical hypoxia and/or ischemia, usually observed in patients with bacterial meningitis, as described elsewheré

Although we could not find statistical significance to associate decreased consciousness level to increased lethality, there is an important tendency to establish this association in our group of patients.

A retrospective study, carried out at the same hospital from 1973 to $1982^{\prime}$, analyzed 4100 admissions for meningitis. Of these cases, children under 15 years of age accounted for $79 \%$. This study revealed an overall case fatality rate of $33 \%$, with $50 \%$ of deaths occurring within 48 hours of admission. Although the authors observed that the overall case fatality rate was lowest in patients from 2 to 15 years of age, there was a lower mortality rate in all the age groups when we compared both populations. However, a majority of patients continues to die within 48 hours of hospitalization. It is possible that better management of the complications and the earlier use of proper antibiotics could be related to the decreased mortality rate observed in our cases. In trial studies in children with bacterial meningitis, dexamethasone has been shown to reduce meningeal inflammation and improve the outcome of disease ${ }^{4,5,7.8}$. Corticosteroids have been utilized systematically as an additional therapy in children with bacterial meningitis admitted to our hospital. However, at the present time, it is not possible to establish the true impact of corticosteroids in our population.

\section{REFERENCES}

1. Bryan JP, Silva HR, Tavares A, Rocha H, Scheld WM. Etiology and mortality of bacterial meningitis in Northeastem Brazil. Rev Inf Dis 1990;12:128-135.

2. Cadoz M, Denis F, Diop Mar I. Etude épidémiologique des cas de méningites purulentes hospitalisés à Dakar pendant la décennie 1970-79. Bull Organis Mond Santé 1981;59:575-584.

3. Ferreira A, Nascimento MHC, Gomes I, Melo A. Neurologic complications in bacterial meningitis. J Neurol 1995;242:(Suppl):S-115.

4. Geiman BJ, Smith AL. Dexamethasone and bacterial meningitis: a metanalysis of randomized controilled trials. West J Med 1992;157:27-31.

5. Girgis NI, Farid Z, Mikhai] IA, Ferrag I, Sultan Y, Kilpatrick ME. Dexamethasone treatment for bacterial meningitis in children and adults. Pediatr Infect Dis J 1989;8:848-851.

6. Herson VC. Todd JK. Prediction of morbidity in H. influenzae meningitis. Pédiatrics 1977;59:35-39.

7. Lebel MH, Freij BJ, Syrogiannopoulos GA et al. Dexamethasone therapy for bacterial meningitis: results of two double blind placebo controlled trials. N Engl J Med 1988;319:964-971.

8. Odio CM, Faingezcht I, Paris $M$ et al. The beneficial effects of early dexametasone administration in infunts and children with bacterial meningitis. N Eng J Med 1991;324:1525-1531.

9. Pfister HW, Borasie GD, Dirnagl U, Buuer M, Einhaupl KM. Cerebrovascular complications of bacterial meningitis in adults. Neurology 1992;42:1497-1504.

10. Pfister HW, Feiden W, Ejnbaupl KM. Spectrum of complications during bacterial meningitis in adults: results of a prospective clinical study. Arch Neurol 1993;50:575-581.

11. Quagliarello V, Scheld WM. Bacteriul meningitis: pathogenesis, pathophysiology and progress. N Engl J Med 1992;327:864-872.

12. Schlesinger LS, Ross SC, Schaberg DR. Staphylococcus aureus meningitis: a broad based epidemiologic study. Medicine 1987;66:148-156.

13. Spanos A, Harrel FE, Durack DT. Differential diagnosis of acute meningitis: an analysis of the predictive value of initial observations. JAMA 1989;2700-2707.

14. Tunkel $A R$, Wispelwey $B$, Scheld $M$. Bacterial meningitis: recent advances in pathophysiology and treatment. Ann Intern Med 1990;112:610-623. 